\title{
A specular microscopic study of families with endothelial dystrophy
}

\author{
JACK I. SCHNITZER AND JAY H. KRACHMER \\ From the Iowa Lions Cornea Center, Department of Ophthalmology, University of Iowa Hospitals, \\ Iowa City, Iowa 52242, USA
}

SUMMARY A prospective study of 12 families in which the proband had Fuchs's dystrophy was undertaken. Forty-four relatives were examined with the clinical specular microscope. Nine relatives, all women over 40 years of age, were affected. The mean endothelial cell density for unaffected relatives was 2889 cells $/ \mathrm{mm}^{2}$ in the right eye and 2923 cells $/ \mathrm{mm}^{2}$ in the left eye. Variability in endothelial cell size was not present in unaffected relatives but was present in those relatives with cornea guttata. Endothelial cell density decreased with age. The mean corneal thickness for unaffected and affected relatives was $0.51 \mathrm{~mm}$ and $0.53 \mathrm{~mm}$, respectively. Unaffected relatives were compared with a control group with respect to endothelial cell density and corneal thickness. No significant difference was found between the 2 groups. In this study the clinical specular microscope failed to differentiate between controls and relatives of patients with Fuchs's dystrophy who at the time of examination did not have endothelial dystrophy. The instrument, therefore, could not be used to identify endothelial characteristics not visible with the slit-lamp which might be the forerunner of endothelial dystrophy.

In 1910 Fuchs, ${ }^{1}$ without the aid of a biomicroscope, described the picture of bilateral corneal oedema in elderly patients. $\mathrm{He}$ postulated an endothelial abnormality. It was not until 1920 that Vogt ${ }^{2}$ viewed the corneal endothelium in vivo in specular illumination with a biomicroscope. In the following year he applied the term 'cornea guttata' to the drop-like excrescences of Descemet's membrane seen in patients with findings similar to those described by Fuchs. ${ }^{3}$ The term 'endothelial dystrophy' is generally used to describe extensive central cornea guttata. When this is seen in combination with corneal oedema the term 'Fuchs's combined dystrophy' is applied.

Endothelial dystrophy is a common condition. A recent study showed a strong familial tendency toward the disease. ${ }^{4}$ Unlike other corneal conditions which can be detected within the first several decades of life endothelial dystrophy usually does not become manifest until after 40 years of age. Therefore the offspring has many years to wonder, and worry, about the 'health' of his eyes.

Correspondence to Dr Jay Krachmer, Department of Ophthalmology, University Hospitals, Iowa City, Iowa 52242, USA.
The corneal endothelium can be viewed directly by means of specular illumination. Unfortunately the view obtained with the slit-lamp does not afford enough magnification critically to analyse cellular morphology. The clinical specular microscope provides this magnification. A study was undertaken to determine whether relatives of patients with Fuchs's dystrophy, who appeared clinically normal on slit-lamp examination, had endothelial abnormalities detectable with the clinical specular microscope.

\section{Subjects and methods}

A prospective study of relatives of patients with Fuchs's dystrophy was undertaken. Whenever a patient with Fuchs's dystrophy was examined at the Iowa Lions Cornea Center, we requested that he inform all his relatives of our desire to examine them. If a family member responded and was examined, a research chart was started for the proband's family. Only families which were not part of a previous prospective study ${ }^{4}$ were included.

The age, sex, race, and presence of systemic disease were noted. The family member was examined with the slit-lamp, and the severity of the 
Table 1 Grading of endothelial dystrophy

\begin{tabular}{ll}
\hline Grade & Central guttata \\
\hline 0 & $\leqslant 12$ \\
1 & $>12$ \\
2 & $1-2 \mathrm{~mm}$, confluent \\
3 & $2-5 \mathrm{~mm}$, confluent \\
4 & $>5 \mathrm{~mm}$, confluent \\
$4+$ & $>5 \mathrm{~mm}$, confluent \\
& with stromal or epithelial oedema \\
\hline
\end{tabular}

Grades $2-4$ considered 'affected.'

endothelial dystrophy was graded (Table 1). The presence of stromal oedema or epithelial oedema was noted separately. The central corneal thickness was measured with a modified Haag-Streit pachometer. ${ }^{5}$

The corneal endothelium was examined and photographed with the Heye-Schulte corneal endothelial microscope. This instrument is equipped with a special eyepiece reticule (a grid of known area), which is superimposed on each photograph, for easy calculation of the endothelial cell density (ECD). Central endothelial photographs were taken. In those patients with confluent guttata where central endothelial cells could not be visualised peripheral (outside the central $5-6 \mathrm{~mm}$ zone) photographs were obtained.

A high-contrast print was made from each Kodak Tri-X negative. Endothelial cells within the area of the grid were counted. Cells touching the borders of the grid were counted on only 2 adjacent sides. The counts were then expressed as cells $/ \mathrm{mm}^{2}$. The 3 best photographs of each eye were counted and the results averaged. In those patients with cornea guttata in the photographic field endothelial cells in that part of the grid free of guttata were counted. The endothelial cell count, for the cornea guttata free area of the grid, was then expressed as cells $/ \mathrm{mm}^{2}$. Cell counts were performed in a masked manner by the same individual. Analysis of cellular morphology, with particular reference to size and shape, was performed in a masked manner. Other family members were examined in a similar fashion.

Age- and sex-matched control subjects were selected at random from patients in the Department of Ophthalmology. Only patients seen either for routine refraction or for decreased vision secondary to cataract were examined. There were examined by the method described above. The purpose of a control population was twofold: (1) for comparison with our study population, and (2) for comparison with ECD reported by other authors.

Student's $t$ test was used to determine the significance level of differences between mean values obtained in the study. A correlation coefficient was determined to compare ECD with corneal thickness and with age.

\section{Results}

Three groups of individuals were examined. They included probands, relatives of probands, and controls. Endothelial cell counts of probands were not possible because of corneal oedema and extensive confluent cornea guttata. Those relatives without confluent guttata (unaffected) were included in the 'study group' and compared with controls. Those with confluent guttata (affected) were not compared with controls because of the difficulty in interpreting their endothelial cell densities. Age- and sex-matched controls comprise the third group. The results, for each group, were tabulated.

A total of 44 relatives of probands were examined in 12 families. Details of the date for each of these subjects may be obtained by applying to the authors. Thirty-five were female and 9 were male. They ranged in age from 6 to 84 years. Nine of the 44 relatives $(20.5 \%)$ examined were affected. All affected relatives were women over 40 years old (range, 44 to 77 years).

Of the 12 families examined only the proband was affected in 6 families. In the remaining 6 families there were 22 people without endothelial dystrophy and 9 affected with endothelial dystrophy.

The results which follow describe the data from relatives without confluent guttata, the study group, compared with controls. The study group included 35 people in 11 families. There were 26 females and 9 males. They ranged from 6 to 84 years of age. The mean age was 30 years (median 26 years). Twenty-six were under 40 and 9 were 40 years of age and older.

Seventeen control subjects were examined. There were 13 females and 4 males. This was $50 \%$ of the number of female and male relatives included in the study group. They ranged from 17 to 68 years of age (mean 34 years, median 30 years). Twelve were under 40 and 5 were over 40 years of age. No control subject had endothelial dystrophy.

The mean endothelial cell density (ECD) was determined for the study group and control subjects for right and left eyes (Table 2). When members of

Table 2 Comparison of study with control groups

\begin{tabular}{|c|c|c|c|c|}
\hline $\begin{array}{l}\text { Age range } \\
\text { years }\end{array}$ & Group & $\begin{array}{l}\text { Number } \\
\text { examined }\end{array}$ & $\begin{array}{l}\text { Mean } \\
\text { densit } \\
R\end{array}$ & $\begin{array}{l}\text { elial cell } \\
\operatorname{mm}_{L}^{2}\end{array}$ \\
\hline $0-84$ & $\begin{array}{l}\text { Study } \\
\text { Control }\end{array}$ & $\begin{array}{l}35 \\
17\end{array}$ & $\begin{array}{l}2889 \\
2808\end{array}$ & $\begin{array}{l}2923 \\
2836\end{array}$ \\
\hline$<40$ & $\begin{array}{l}\text { Study } \\
\text { Control }\end{array}$ & $\begin{array}{l}26 \\
12\end{array}$ & $\begin{array}{l}3042 \\
2935\end{array}$ & $\begin{array}{l}3072 \\
2976\end{array}$ \\
\hline$\geqslant 40$ & $\begin{array}{l}\text { Study } \\
\text { Control }\end{array}$ & $\begin{array}{l}9 \\
5\end{array}$ & $\begin{array}{l}2449 \\
2505\end{array}$ & $\begin{array}{l}2490 \\
2501\end{array}$ \\
\hline
\end{tabular}




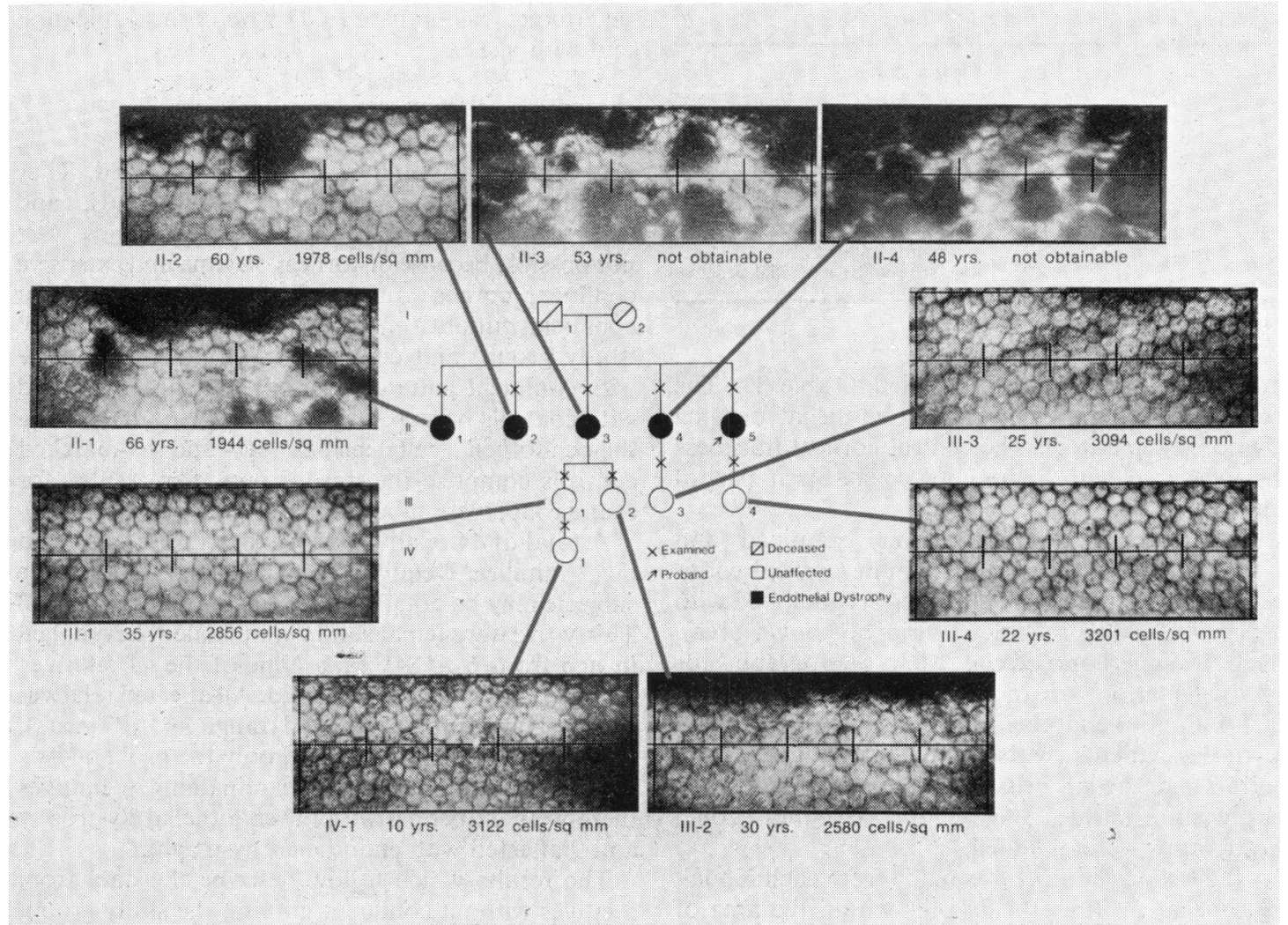

Fig. 1 Pedigree and specular photomicrographs of corneal endothelial cells (grid $=317 \cdot 5 \mu \mathrm{m} \times 127 \mu \mathrm{m}$ ) from members of a family with Fuchs's dystrophy. The proband, 45 years old, could not be photographed because of corneal oedema and extensive confluent cornea guttata. In generation II the normal endothelial mosiac is disrupted by cornea guttata.

the study group were considered without regard to age or sex the mean ECD was 2889 cells $/ \mathrm{mm}^{2}$ in the right eye and 2923 cells $/ \mathrm{mm}^{2}$ in the left eye. The mean ECD for all control subjects was 2808 cells $/ \mathrm{mm}^{2}$ in the right eye and 2836 cells $/ \mathrm{mm}^{2}$ in the left eye. There was no significant differences in ECD between the right eye and the left eye in either group $(p>0 \cdot 1)$. No significant differences in ECD was found between the study group and the control group when compared as a whole $(p>0.25)$, for those under 40 years of age $(p>0 \cdot 1)$, or for those 40 years of age or older $(p>0 \cdot 40)$. No difference in endothelial cell morphology was observed between the 2 groups.

Specular photomicrographs of corneal endothelial cells from one of the families are included with the pedigree in Fig. 1. Endothelial cell densities illustrated the mean value for both eyes of the relative. They are not the counts for the particular photograph in the figure.

The 45-year-old female proband with Fuchs's dystrophy could not be photographed because of corneal oedema and extensive central confluent cornea guttata. Her 66-year-old sister (II-1) and 60-year-old sister (II-2) had grade 3 endothelial dystrophy. Peripheral cell counts on these relatives were 1944 and 1978 cells $/ \mathrm{mm}^{2}$ respectively. The 53-year-old sister (II-3) and 48-year-old sister (II-4) had grade 4 endothelial dystrophy with oedema (Fuchs's dystrophy). The ECD could not be determined.

A 25-year-old daughter (III-3) of II-4 had grade 1 cornea guttata with a mean ECD of 3094 cells $/ \mathrm{mm}^{2}$. The remainder of the family whom we were able to examine did not have corneal guttata. Their endothelial cells were not significantly different from the controls in terms of either cell densities or morphology.

The mean ECD for the study group compared with the control population by age with regard to sex, was determined for each eye. The mean ECD for all female relatives was 2828 cells $/ \mathrm{mm}^{2}$ and for all female control subjects was 2897 cells $/ \mathrm{mm}^{2}$. No 
significant difference in ECD was found between female relatives and female controls when compared as a whole $(p>0.25)$, for those under 40 years of age $(p>0 \cdot 1)$, or for those 40 years of age and older $(\mathrm{p}>0 \cdot 3)$. The mean ECD for all male relatives was 3132 cells $/ \mathrm{mm}^{2}$.

The mean corneal thickness for the study group, affected relatives (apart from those with clinically apparent corneal oedema), and controls was $0.51 \mathrm{~mm}$ (SD, 0.02), $0.53 \mathrm{~mm}$ (SD, 0.01), and $0.51 \mathrm{~mm}$ (SD, 0.02 ). A significant difference in mean corneal thickness was found between the study group and affected relatives without apparent corneal oedema $(\mathrm{p}<0.005)$, whereas no significant difference was found between the study and the control groups $(\mathrm{p}>0.45)$.

The relationship between ECD and age and between ECD and corneal thickness was determined. There was a significant correlation bweteen ECD and age $(r=-0.83)$, but not between ECD and corneal thickness $(r=-0 \cdot 18)$.

\section{Discussion}

The clinical specular microscope allows examination of the corneal endothelium at sufficient magnification to study endothelial cell density and morphology So far its primary use has been to study the effect of intraocular surgery on the endothelium. A varying degree of endothelial cell loss following intraocular surgery has been reported. A gradual decrease in ECD with age also has been noted. ${ }^{6}$

The natural history of Fuchs's dystrophy, progressing from endothelial dystrophy, without corneal oedema, to corneal oedema, has been recognised. However, the progression from a clinically normalappearing endothelium to cornea guttata, or the progression to a worse grade of endothelial dystrophy, has not been well documented. The most likely explanation for this is that young people are not followed-up at regular intervals for a long enough period of time, so the gradual development of cornea guttata is not observed. By the time a person presents to the ophthalmologist for regularly scheduled examinations he is usually in his forties and has already developed confluent cornea guttata.

An increased frequency of endothelial dystrophy occurring in families, in women, and with age has been reported. $48 \%$ of the relatives older than 40 years of age were affected. From those statistics approximately 10 of the 26 persons under 40 in our study group would be expected to develop endothelial dystrophy. So far, however, the 26 relatives do not show morphological endothelial abnormalities.

Age- and sex-matched individuals were selected for our control population. Their endothelial cell densities were in agreement with those reported by other authors. ${ }^{6-9}$ Therefore we feel that our control population, although small in number, is representative.

The mean ECD in our study group, with respect to age, was not significantly different from the control group (Table 2). The ECD was actually higher in the study group than in the control group, with the greatest difference in those people less than 40 years of age. A gradual decrease in mean endothelial cell density with age was also found $(r=-0 \cdot 83)$.

A greater incidence of endothelial dystrophy in females has been consistently recognised. Of the 18 blood relatives aged 40 and older 8 of $16(50 \%)$ females and 0 of 2 males were affected. When ECD was examined with respect to sex, female relatives showed no significant difference when compared with female control subjects. We cannot explain the higher cell counts found in male relatives than in female relatives.

When endothelial cell morphology was evaluated, no difference was observed between the study and control groups. However, since morphology was evaluated without the aid of sophisticated computerised methods, very slight differences cannot be ruled out.

Corneal thickness is one parameter of endothelial cell function. Corneal thickness was $4 \%$ greater in those with confluent cornea guttata (excluding those with clinically apparent corneal oedema) than in the study group (unaffected relatives) $(p<0.005)$. This might demonstrate endothelial dysfunction in people with confluent cornea guttata. An increased corneal thickness and endothelial cell permeability has been found in patients with cornea guttata. ${ }^{10}$

The lack of correlation between endothelial cell density and corneal thickness is not surprising $(r=-0 \cdot 18)$. Studies of the corneal endothelium following intraocular surgery show a remarkable functional reserve. Cell counts under 400 cells $/ \mathrm{mm}^{2}$ have been associated with clear corneas. ${ }^{11} 12$

In those relatives with confluent cornea guttata we obtained central endothelial cell counts in the 3 with grade 2 endothelial dystrophy, peripheral cell counts in the 4 with grade 3 endothelial dystrophy, and no counts in the 2 with Fuchs's dystrophy. In healthy eyes peripheral endothelial cell counts do not differ significantly from central counts. ${ }^{8}{ }^{9}$ Affected relatives had central endothelial cell counts which ranged from 1537 to 3256 cells $/ \mathrm{mm}^{2}$ and peripheral counts which ranged from 1942 to 2635 cells $/ \mathrm{mm}^{2}$

Although these cell densities are within the range of normal for that particular age group, the significance of this surprising finding is not clear. It may be that not until late in the course of the disease does endothelial cell loss increase dramatically. However, 
in patients with confluent cornea guttata the clinical specular microscope cannot yet be used to evaluate cells over the cornea guttata. Therefore we cannot determine if their peripheral and/or central endothelial cell densities are representative of the entire cornea.

The endothelial cells of the patient with cornea guttata which could be visualised were more variable in size and shape than those in the study or the control group.

In this study the clinical specular microscope established the presence of a normal endothelial cell population in those relatives of patients with Fuchs's dystrophy who appeared clinically normal on slit-lamp examination. Endothelial cell density, endothelial cell morphology, and corneal thickness did not distinguish these individuals from a control population. Perhaps other studies of endothelial cell function might give that information.

This study was supported in part by a Heed Foundation fellowship (Dr Schnitzer). Robert B. Taylor performed the endothelial cell density counts.

\section{References}

1 Fuchs E. Dystrophia epithelialis corneae. Albrecht von Graefes Arch Klin Ophthalmol 1910; 76: 478-508.
2 Vogt A. Die Sichtbarkeit des lebenden hornhautendothels. Albrecht von Graefes Arch Klin Ophthalmol 1920; 101: 123-44.

3 Vogt A. Weitere ergebnisse der spaltlampenmikrospie des vordern Bulbusabschnittes. Albrecht von Graefes Arch Klin Ophthalmol 1921; 106: 63-103.

4 Krachmer JH, Purcell JJ, Young CW, Bucher KD. Corneal endothelial dystrophy: a study of 64 families. Arch Ophthalmol 1978; 96: 2036-9.

5 Mishima S, Hedbys BC. Measurement of corneal thickness with the Haag-Streit pachometer. Arch Ophthalmol $1968 ; 80: 710-3$.

6 Bourne WM, Kaufman HE. Specular microscopy of human corneal endothelium in vivo. Am J Ophthalmol 1976; 81 : 319-23.

7 Hirst LW, Snip RC, Stark WJ, Maumenee AE. Quantative corneal endothelial evaluation in intraocular lens implantation and cataract surgery. Am J Ophthalmol 1977; 84: 775-80.

8 Blackwell WL, Gravenstein N, Kaufman HE. Comparison of central corneal endothelial cell numbers with peripheral areas. Am J Ophthalmol 1977; 84: 473-6.

9 Hoffer KJ. Vertical endothelial cell disparity. Am J Ophthalmol 1979; 87: 344-9.

10 Burns RR, Bourne WM, Brubaker RF. Endothelial function in patients with cornea guttata. Invest Ophthalmol Visual Sci 1979; Supplement: 37.

11 Bourne WM, Kaufman HE. The endothelium of clear corneal transplants. Arch Ophthalmol 1976; 94: 1730-2.

12 Forstot SL, Blackwell WL, Jaffe NS, Kaufamn HE. The effect of intraocular lens implantation on the corneal endothelium. Trans Am Acad Ophthalmol Otolaryngol 1977; 83: 195-203. 